\title{
Variations in Suppressor Molecule $C T L A-4$ Gene Are Related to Susceptibility to Multiple Myeloma in a Polish Population
}

\author{
Lidia Karabon • Edyta Pawlak-Adamska • Anna Tomkiewicz • Anna Jedynak • \\ Marek Kielbinski • Dariusz Woszczyk • Stanisław Potoczek • Anna Jonkisz • \\ Kazimierz Kuliczkowski • Irena Frydecka
}

Received: 29 October 2010 / Accepted: 22 June 2011 / Published online: 9 July 2011

(C) The Author(s) 2011. This article is published with open access at Springerlink.com

\begin{abstract}
Various phenotype and functional T-cell abnormalities are observed in multiple myeloma (MM) patients. The aim of this study was to investigate the association between polymorphisms in the gene encoding cytotoxic Tlymphocyte antigen-4 (CTLA-4), a negative regulator of the T-lymphocyte immune response and susceptibility to multiple myeloma in a Polish population. Two hundred MM patients and 380 healthy subjects were genotyped for the following polymorphisms: CTLA-4c.49A $>\mathrm{G}$, CTLA4g.319C $>$ T, CTLA-4g. ${ }^{*} 642 \mathrm{AT}\left(8 \_33\right)$, CT60 (CTLA-4g.
\end{abstract}

L. Karabon • E. Pawlak-Adamska • A. Tomkiewicz • A. Jedynak · I. Frydecka

Department of Experimental Therapy, Institute of Immunology and Experimental Therapy, Polish Academy of Sciences,

Weigla 12 ,

53-114 Wroclaw, Poland

M. Kielbinski $\cdot$ S. Potoczek $\cdot$ K. Kuliczkowski $\cdot$ I. Frydecka Department of Hematology, Neoplastic Diseases \& Bone Marrow Transplantation, Medical University,

Pasteura 1,

50-367 Wroclaw, Poland

D. Woszczyk

Department of Hematology, State Hospital,

ul. Kosnego 53,

Opole, Poland

A. Jonkisz

Department of Forensic Medicine, Medical University,

Curie Skłodowskiej 52,

50-369 Wroclaw, Poland

L. Karabon $(\bowtie)$

Institute of Immunology and Experimental Therapy,

Polish Academy of Science,

ul. Weigla 12,

Wroclaw, Poland

e-mail: 1karabon@iitd.pan.wroc.pl
*6230G $>$ A), Jo31 (CTLA-4g.*10223G>T). Our study is the largest and most comprehensive evaluation to date of the association between genetic polymorphisms in the CTLA-4 molecule and multiple myeloma. It was found that $C T L A-4 \mathrm{c} .49 \mathrm{~A}>\mathrm{G}[\mathrm{G}], \mathrm{CT} 60[\mathrm{G}]$, and Jo31[G] alleles were more frequently observed in $\mathrm{MM}$ patients than in controls $(0.50$ vs. $0.44, p=0.03,0.65$ vs. $0.58, p=0.04$, and 0.63 vs. $0.57, p=0.03$, respectively). Moreover, the haplotype CTLA-4c.49A $>\mathrm{G}[\mathrm{G}], C T L A-4 \mathrm{~g} .319 \mathrm{C}>\mathrm{T}[\mathrm{C}]$, CTLA-4g.*642AT(8_33) [8], CT60[G], Jo31[G] including all susceptibility alleles increases the risk of MM about fourfold (OR: 3.79, 95\%CI: 2.08-6.89, $p=0.00001$ ). These findings indicate that genetic variations in the CTLA-4 gene play role in susceptibility to multiple myeloma and warrant further investigation through replication studies.

Keywords CTLA-4 $\cdot$ Gene polymorphisms $\cdot$ MM

\section{Introduction}

Multiple myeloma (MM) is a B-cell neoplasm characterized by the proliferation and accumulation of isotype-switched immunoglobulin-producing monoclonal plasma cells in the bone marrow and by overproduction of monoclonal immunoglobulins that can be detected in serum and/or urine. Previous studies reported that MM patients may exhibit a variety of T-cell abnormalities, such as a marked reduction in the proportions of CD4 and CD8 cells expressing co-stimulatory molecules, signal transduction components, and Th1/Th2 imbalance, particularly in advanced stages of MM [1-5]. The involvement of altered Tcell response in the development of murine plasmacytomas has also been reported [6]. The effective activation of naïve 
T-cells requires two independent signals. The first, an antigen-specific signal, is sent via a unique antigen receptor, the T-cell receptor (TCR), on T-cells. The second signal, termed co-stimulation, is critical for allowing full activation, sustaining cell proliferation, preventing anergy and/or apoptosis, inducing differentiation to effector and memory status, and allowing cell-cell cooperation. CD28 is the primary T-cell co-stimulatory molecule and is constitutively expressed on the majority of T-cells. Cytotoxic T-cell antigen (CTLA-4) is a homologous molecule of $\mathrm{CD} 28$ which plays an inhibitory role in the early and late stages of T-cell activation [7]. CTLA-4 ligation provides a negative signal for regulation of the cell cycle and inhibits the activity of the transcriptional factors: nuclear factor $-\mathrm{kB}(\mathrm{NF}-\mathrm{kB})$, nuclear factor of activated $\mathrm{T}-$ cells (NF-AT), and activator protein 1 (AP-1). Moreover, CTLA-4 binds to CD28 ligands (CD80 and CD86) with higher affinity and avidity and in that way also inhibits $\mathrm{T}$ cell activation [8].

Several reports have indicated that CTLA-4 gene polymorphisms are implicated in malignancies [9-14]. To the best of our knowledge, no large cohort-based study on gene polymorphisms of co-stimulatory and down-regulatory molecules has been performed in MM. Only one report was devoted to an association between the CTLA-4g. ${ }^{*} 642 \mathrm{AT}$ (8_33) polymorphism and susceptibility to MM [15]. Therefore we undertook a study to investigate the relationship between CTLA-4c.49A $>\mathrm{G}$ (rs231775), CTLA4g.319C $>$ T (rs5742909), CTLA-4g.*642AT(8_33), CTLA4g6230G $>$ A (CT60, rs3087243), CTLA-4g.10223G $>$ T (Jo31, rs11571302) gene polymorphisms and MM incidence, age at disease onset, ISS, M component type, light chain, response to treatment, and time to disease progression.

The polymorphic markers we chose for our study are reported to be functional and to be associated with altered immune responses. The CTLA-4g. 319C $>$ T single nucleotide polymorphism (SNP) influences promoter activity and the expressions of both CTLA-4 mRNA in unstimulated cells and cell-surface CTLA-4 on activated cells [16-19]. The $\mathrm{A}>\mathrm{G}$ transition at position 49 in exon (CTLA$4 c .49 \mathrm{~A}>\mathrm{G}$ ) causes a $\mathrm{Thr} / \mathrm{Ala}$ substitution in the leader peptide [20]. This polymorphism affects the inhibitory function of CTLA-4 [16, 21]. The dinucleotide short repeat polymorphism CTLA-4g.*642AT(8_33) at position 642 in the 3 'untranslated region (UTR) influences the level of mRNA transcription [22]. The CTLA-4g.* $6230 \mathrm{G}>\mathrm{A}$ (CT60) polymorphism was shown to be associated with variations in the mRNA level of soluble CTLA-4 [24]. Results published by us indicate that the Jo31 polymorphism together with CT60 is associated with the levels of membrane and cytoplasmic CTLA-4 in CD4+ T lymphocytes from multiple sclerosis patients [23] and with the variation of serum soluble CTLA-4 level in Graves-Basedow patients [24]. Moreover, all the investigated polymorphisms are associated with susceptibility to malignancies [9, 11-14].

The results from the present study indicate that CTLA-4 gene polymorphisms are related to susceptibility to multiple myeloma in a Polish population.

\section{Materials and Methods}

\section{Study Population}

The study enrolled 200 unrelated Polish patients with multiple myeloma came from two centers: 148 from the Department of Haematology, Neoplastic Diseases \& Bone Marrow Transplantation of the Medical University in Wroclaw, and 52 from the Department of Haematology of the State Hospital in Opole. There were 106 women and 94 men aged 33 to 85 (median $\pm \mathrm{SD}, 67 \pm 10.9$ years), and the median age at diagnosis was $63.5 \pm 11.2$ years. The diagnosis of multiple myeloma was based on criteria established by the International Myeloma Working Group [25]. Clinical stage was assessed according to the International Staging System (ISS) for Multiple Myeloma and was determined during enrolment in the study [26], i.e. stage 1 with serum $\beta 2$ microglobulin less than $3.5 \mathrm{mg} / 1$ + serum albumin $\geqq 3.5 \mathrm{~g} / \mathrm{dl}$, stage 2 with neither stage 1 nor 3 , and stage 3 with serum $\beta 2$ microglobulin level $\leq 5.5 \mathrm{mg} /$ 1. The patients were treated according to the melphalan+ prednisone (MP); vincristine, doxorubicin (Adriamycin), dexamethasone (VAD); vincristine, melphalan, cyclophosphamide, prednisone (VMCP); or cyclophosphamide, thalidomide, dexamethasone (CTD) protocol. Table 1 summarizes the clinical characteristics of the MM patients.

The control group included 380 healthy Polish individuals originating from the same geographical area as the patients (214 female and 166 male) with the majority recruited from the blood bank in Wroclaw and others recruited among employees of the Institute of Immunology and Experimental Therapy. Genetic homogenity of the Polish population is observed, as reflected in virtually identical frequencies of $\mathrm{H}-\mathrm{Y}$ polymorphisms in different regions of Poland [27]. All enrolled participants were informed about the study protocols and consent was obtained from each individual. Data on participation rate were not available. The study was approved by the local ethics committee.

\section{Genotyping/Determination of Polymorphisms}

A single nucleotide polymorphisms (SNPs) g. $319 \mathrm{C}>\mathrm{T}$ in the promoter region, c.49A $>\mathrm{G}$ in exon 1 , and CT60 in the 3'UTR of the CTLA-4 gene were examined by polymerase chain reaction-restriction fragment length polymorphism 
Table 1 Patients' characteristics

\begin{tabular}{|c|c|c|}
\hline \multicolumn{2}{|l|}{ Number of patients } & 200 \\
\hline \multicolumn{2}{|l|}{$\begin{array}{l}\text { Age (median, st. } \\
\text { dev., range) }\end{array}$} & $\begin{array}{r}67 \pm 10.7 \\
(33-87)\end{array}$ \\
\hline \multicolumn{2}{|l|}{$\begin{array}{r}\text { Age of onset } \\
\text { (median, st. } \\
\text { dev., range) }\end{array}$} & $\begin{array}{c}63.5 \pm 11.2 \\
(32-84)\end{array}$ \\
\hline \multicolumn{2}{|l|}{$\begin{array}{l}\text { Gender } \\
\text { (female/male) }\end{array}$} & $106 / 94$ \\
\hline \multirow{3}{*}{$\begin{array}{l}\text { International } \\
\text { Staging System } \\
\text { (ISS) }\end{array}$} & 1 & 73 \\
\hline & 2 & 66 \\
\hline & 3 & 61 \\
\hline \multirow[t]{7}{*}{ Ig subtype } & $\operatorname{IgG}$ & 115 \\
\hline & $\operatorname{IgA}$ & 45 \\
\hline & $\operatorname{IgM}$ & 5 \\
\hline & $\operatorname{IgD}$ & 1 \\
\hline & Non-secretory & 4 \\
\hline & Light chain & 13 \\
\hline & others & 17 \\
\hline \multirow[t]{2}{*}{ Light chain type } & K & $67 \%$ \\
\hline & $\lambda$ & $33 \%$ \\
\hline \multicolumn{2}{|l|}{ Number of controls } & 380 \\
\hline & volunteers of blood bank & 329 \\
\hline & $\begin{array}{l}\text { employee of Institute of } \\
\text { Immunology\& Experimental } \\
\text { Therapy }\end{array}$ & 51 \\
\hline \multicolumn{2}{|c|}{ Gender of controls (female/male) } & $214 / 166$ \\
\hline
\end{tabular}

(PCR-RFLP) using TruI, BseXI, and TailI enzymes (Fermentas, Burlington Ontario, Canada). Table 2 lists the conditions of PCR product digestion with the restriction enzymes. Table 3 lists the primer sequences for PCR. The PCR reaction was carried out as described previously.

The Jo31 CTLA-4 gene polymorphism was genotyped by the allelic discrimination method on the Applied Biosystems 7300 Real-Time PCR System using the TaqMan SNP Genotyping Assay-on -Demand (Applied Biosystems, Warrington, UK).

The CTLA-4 3' UTR containing (AT)n repeats was amplified with a pair of primers (listed in Table 3 ) in which the $5^{\prime}$ ends of the forward primers were labelled with JOE and 6-FAM, respectively (Bionovo, Legnica, Poland). The detailed procedure is described in Suwalska et al. [9].

For quality controls we performed $5 \%$ to $10 \%$ re-typing with double blind check. For all SNPs additionally typing with other genotyping methods was used. Re-typing methods were as follows: g.319C $>$ T SNP in the promoter region, c.49A $>\mathrm{G}$ in exon 1 , and $\mathrm{CT} 60$ in the $3^{\prime}$ UTR of the CTLA-4 gene were genotyped using PCR and then singlenucleotide primer-extension methods as described in Suwalska et al. [9], while the Jo31 SNP was genotyped using PCR and then single-nucleotide primer-extension methods as described in Karabon et al. [23].

The primers were designed according to the complete CTLA-4 gene sequence derived from the NCBI Sequence Viewer.

\section{Statistical Analyses}

The evaluation of Hardy-Weinberg equilibrium was performed independently for the patients and control group by comparing the observed and expected frequencies of genotypes using $\chi^{2}$ analysis. The $\chi^{2}$ test was used to compare categorical data between patients with $\mathrm{MM}$ and controls. Odds ratios (OR) and 95\% confidence intervals $(95 \% \mathrm{CI})$ were calculated using the binary logistics regression model. The linkage disequilibrium (LD) coefficients $\mathrm{D}^{\prime}=\mathrm{D} / \mathrm{D}_{\max }$ and $r^{2}$ for the pair of the most common alleles at each locus and haplotype frequencies for pairs of alleles were determined using the SHEsis program (http://202.120.7.14/ analysis/myAnalysis.php) [28]. Haplotypes with frequencies lower than 0.03 were not considered.

\section{Results}

CTLA-4 Polymorphisms and Susceptibility to MM

The distributions of the alleles and genotypes of all studied polymorphisms in the MM patients and the healthy control group are shown in Table 4. Neither in cases nor in controls was deviation from Hardy-Weinberg equilibrium observed

Table 2 Conditions for PCR product digestion with restriction enzymes

\begin{tabular}{lllll}
\hline Amplicon [bp] & SNP & Enzyme & Temperature and duration of digestion & Digestion products visible on gel [bp] \\
\hline 814 & CTLA-4g.319C $>\mathrm{T}$ & TruI & $65^{\circ} \mathrm{C}, 3 \mathrm{~h}$ & C: $51,101,100,562$ \\
& & & T: $51,101,100,94,468$ \\
814 & CTLA-4c.49A $>\mathrm{G}$ & BseXI & $65^{\circ} \mathrm{C}, 4 \mathrm{~h}$ & A: 207,607 \\
& & & G: $207,508,99$ \\
& TT60 & & & G: $419,236,151$ \\
& & & & A: 236,570 \\
\hline
\end{tabular}


Table 3 Primer sequences and annealing temperatures used for CD28, CTLA-4, and ICOS genotyping.

\begin{tabular}{|c|c|c|c|c|}
\hline Polymorphic site & Type of reaction & Primer sequence & Product size $[\mathrm{bp}]$ & $\mathrm{T}_{\mathrm{m}}\left[{ }^{\circ} \mathrm{C}\right]$ \\
\hline $\begin{array}{l}C T L A-4 \mathrm{c} .49 \mathrm{~A}>\mathrm{G}(\mathrm{rs} 231775) \\
C T L A-4 \mathrm{~g} .319 \mathrm{C}>\mathrm{T}(\mathrm{rs} 5742909)\end{array}$ & PCR & $\begin{array}{l}\text { F: } 5^{\prime}-\mathrm{TCT} \text { TTT CCg CCT ATT TTC AgT T- } 3^{\prime} \\
\text { R: } 5^{\prime}-\text { CAC CTC CTC CAT CTT CAT gCT CC }-3^{\prime}\end{array}$ & 814 & 58 \\
\hline CT60 (rs3087243) & PCR & $\begin{array}{l}\text { F: } 5^{\prime}-\text { Tgg gCC CAATTC TTA CAA AC }-3^{\prime} \\
\text { R: } 5^{\prime}-\text { CAg gAT gTg gAg gTC AAA AA- } 3^{\prime}\end{array}$ & 806 & 58 \\
\hline CTLA-4g.*642AT(8_33) & PCR & $\begin{array}{l}\text { F: (JOE) 5'-gCC AgT gAT gCT AAA ggT Tg-3' } \\
\text { R: } 5^{\prime}-\mathrm{TgC} \text { CAg TTC CCT ACA AgA Ag-3' }\end{array}$ & $82-132$ & 52 \\
\hline
\end{tabular}

(Table 4). The odds ratios (OD) and 95\% confidence intervals $(\mathrm{CI})$ in Table 4 are shown for the codominant model. For the microsatellite polymorphism CTLA-4g. *642AT(8_33) the alleles were grouped arbitrarily into two groups, i.e. short ([8] 8 repeats) and long ([>8], $>8$ repeats) alleles.

The exon 1 CTLA-4 gene polymorphism at position +49 was found to be associated with MM. The frequency of the CTLA-4c.49A $>\mathrm{G}[\mathrm{G}]$ allele was significantly higher in the MM patients than in the controls $(p=0.03)$, with an estimated odds ratio (OR) of 1.31 and a $95 \%$ confidence interval (CI) of 1.03-1.68. Moreover, the distributions of the genotypes were different in the patients and controls. Individuals possessing [G] alleles (genotypes [GG] and [AG]) were present significantly more frequently among patients than controls ( $p=0.02$, OR: 1.61, 95\%CI: 1.08-2.44).

Moreover, the Jo31 SNP contributed to the risk of MM. The Jo31 [G] allele and [GG] genotype were associated with increased the risk of MM (OR: $1.32, p=0.03$, 95\%CI: $1.03-$ 1.69 and OR: $1.46, p=0.04,95 \% \mathrm{CI}: 1.02-2.08$, respectively) (Table 4).

Additionally we noted a significantly higher frequency of the CT60 [G] allele and a trend toward over-expressing the $[\mathrm{GG}]$ genotype in MM patients compared with controls ( $p=0.04$, OR: 1.3 , 95\%CI: $1.11-1.68$ and $p=0.07$, OR: 1.41, 95\%CI: 0.97-1.99, respectively) (Table 4).

The distribution of alleles and genotypes in CTLA4g.319C $>\mathrm{T}$ and CTLA-4g.*642AT(8_33), polymorphisms did not differ between the group of $\mathrm{MM}$ patients and controls.

The global distributions of the haplotypes differed significantly between the cases and controls ( $\mathrm{p}_{\text {after Bonferroni }}$ correction $=7.5 \mathrm{e}-005)$ (Table 5). The haplotype CTLA4c.49A $>\mathrm{G}[\mathrm{G}] / C T L A-4 \mathrm{~g} .319 \mathrm{C}>\mathrm{T}[\mathrm{C}] / C T L A-4 \mathrm{~g} . * 642 \mathrm{AT}$ (8_33)[8]/CT60[G]/Jo31[G] was overrepresented in the cases compared with the controls (OR: 3.79, 95\%CI: $2.08-$ 6.89, $p=0.00001$ ).

CTLA-4 Gene Polymorphisms and Clinical Data in Multiple Myeloma Patients

Because multiple myeloma occurs more frequently in males than in females, we conducted a separate association test of all the studied polymorphic markers, i.e., CTLA-4c.49A $>\mathrm{G}$, CTLA-4g.319C >T, CTLA-4g.*642AT(8_33), CT60, and Jo31 in the CTLA-4 gene in male and female participants. We noted an even stronger association between the CTLA4c.49A $>\mathrm{G}[\mathrm{G}]$ allele and susceptibility to $\mathrm{MM}$ in males (OR:1.61, 95\%CI:1.11-2.33, $p=0.01$ ). None of the studied polymorphic markers correlated with the clinical data regarding: age at disease onset, ISS, M component type, light chain, response to treatment, or time to disease progression.

\section{Linkage Disequilibrium}

The investigated polymorphisms in the 3' UTR, namely, Jo31, CT60, and CTLA-4g.*642AT(8_33) were in strong linkage disequilibrium with each other expressed by either $\mathrm{D}^{\prime}$ or $\mathrm{r}^{2}$ (Table 6). In the case of pairs $C T L A-4 \mathrm{c} .49 \mathrm{~A}>\mathrm{G}$ and CTLA-4g.319C $>\mathrm{T} ;$ CTLA-4c.49A $>\mathrm{G}$ and CTLA-4g. *642AT (8_33); CTLA-4g.319C $>\mathrm{T}$ and CTLA-4g.*642AT(8_33); $C T L A-4 \mathrm{c} .49 \mathrm{~A}>\mathrm{G}$ and $\mathrm{CT} 60 ; C T L A-4 \mathrm{c} .49 \mathrm{~A}>\mathrm{G}$ and $\mathrm{Jo31}$; CTLA-4g.319C $>\mathrm{T}$ and CT60; and CTLA-4g.319C $>\mathrm{T}$ and Jo31 linkage disequilibrium between them was expressed by $\mathrm{D}^{\prime}$ (Table 6).

\section{Discussion}

Both genetic and environmental factors have been associated with an increased risk of MM.

Family history of $\mathrm{MM}$ in a first-degree relative suggested that genetic variation plays a role in the etiology of multiple myeloma [29]. The genetic susceptibility to multiple myeloma has not been extensively studied, although some studies have evaluated polymorphisms in immune response genes especially cytokine [30-32]. Others were devoted to variations in genes involved in xenobiotics metabolism [33], DNA repair [34], the cell cycle and apoptosis [35].

Genes encoding proteins involved in T-cell activation and suppression have been considered as candidate genes for many autoimmune [36-38] and, recently, also for neoplastic diseases $[9,13,14]$. Only one study was devoted to the association of one polymorphic marker of the CTLA4 gene and multiple myeloma [15]. 
Table 4 CTLA-4c.49A>G, CTLA-4g.319C>T,CTLA-4g.*642AT(8_32), CT60G>A, genotypes and alleles frequencies in MM patients and controls

\begin{tabular}{|c|c|c|c|c|c|c|c|c|}
\hline & & & Multiple myeloma $n=200$ & Controls group $n=380$ & $\mathrm{p}$ & OR & $95 \% \mathrm{CI}$ & Global p \\
\hline \multirow[t]{7}{*}{ CTLA-4c.49A>G } & \multirow[t]{2}{*}{ Allele } & $\mathrm{A}$ & $199(50.0 \%)$ & $417(56.3 \%)$ & 0.03 & 0.77 & $0.60-0.97$ & \\
\hline & & G & $199(50.0 \%)$ & $318(43.7 \%)$ & & 1.31 & $1.03-1.68$ & \\
\hline & \multirow[t]{3}{*}{ Genotype } & $\mathrm{A} / \mathrm{A}$ & $48(24.1 \%)$ & $124(33.4 \%)$ & reference & & & \\
\hline & & $\mathrm{A} / \mathrm{G}$ & $103(51.8 \%)$ & $169(45.6 \%)$ & 0.03 & 1.57 & $1.04-2.38$ & 0.07 \\
\hline & & $\mathrm{G} / \mathrm{G}$ & $48(24.1 \%)$ & $75(21.0 \%)$ & 0.04 & 1.65 & $1.01-1.86$ & \\
\hline & \multirow[t]{2}{*}{ Carriers of } & $\mathrm{G}^{+}$ & $151(76.9 \%)$ & $244(66.6 \%)$ & 0.02 & 1.61 & $1.08-2.44$ & \\
\hline & & G- & $48(24.1 \%)$ & $124(33.4 \%)$ & & 0.63 & $0.41-0.93$ & \\
\hline \multirow[t]{7}{*}{$C T L A-4 g .319 C>T$} & \multirow[t]{2}{*}{ Allele } & $\mathrm{C}$ & $356(89.4 \%)$ & $672(90.2 \%)$ & 0.64 & 0.90 & $0.61-1.36$ & \\
\hline & & $\mathrm{T}$ & $42(10.6 \%)$ & $72(9.8 \%)$ & & 1.10 & $0.73-1.64$ & \\
\hline & \multirow[t]{3}{*}{ Genotype } & $\mathrm{CC}$ & $155(79.5 \%)$ & $297(80.9 \%)$ & reference & & & \\
\hline & & $\mathrm{CT}$ & $40(20.5 \%)$ & $68(18.5 \%)$ & 0.59 & 1.13 & $0.73-1.74$ & 0.43 \\
\hline & & $\mathrm{TT}$ & $0(0.0 \%)$ & $2(0.6 \%)$ & 0.86 & - & - & \\
\hline & \multirow[t]{2}{*}{ Carriers of } & $\mathrm{T}+$ & $40(20.5 \%)$ & $70(19.1 \%)$ & 0.68 & 1.09 & $0.71-1.698$ & \\
\hline & & $\mathrm{T}-$ & $155(79.5 \%)$ & $297(80.9 \%)$ & & 0.91 & $0.59-1.41$ & \\
\hline \multirow[t]{7}{*}{$C T L A-4 g . * 642 A T\left(8 \_32\right)$} & \multirow[t]{2}{*}{ Allele } & 8 & $190(47.5 \%)$ & $350(46.1 \%)$ & 0.64 & 1.06 & $0.83-1.35$ & \\
\hline & & $>8$ & $210(52.5 \%)$ & $410(53.9 \%)$ & & 0.94 & $0.74-1.20$ & \\
\hline & \multirow[t]{3}{*}{ Genotype } & $8 / 8$ & $55(27.5 \%)$ & $94(24.7 \%)$ & reference & & & \\
\hline & & $8 />8$ & $80(40.0 \%)$ & $162(42.6 \%)$ & 0.43 & 0.84 & $0.55-1.82$ & 0.74 \\
\hline & & $>8 />8$ & $65(32.5 \%)$ & $124(32.6 \%)$ & 0.63 & 0.89 & $0.57-1.40$ & \\
\hline & \multirow[t]{2}{*}{ Carriers of } & $8+$ & $135(67.5 \%)$ & $256(68.4 \%)$ & 0.97 & 1.00 & $0.70-1.45$ & \\
\hline & & $8^{-}$ & $65(32.5 \%)$ & $124(32.6 \%)$ & & 0.99 & $0.69-1.43$ & \\
\hline \multirow[t]{7}{*}{$C T 60 G>A$} & \multirow[t]{2}{*}{ Allele } & G & $249(64.5 \%)$ & $444(58.4 \%)$ & 0.04 & 1.30 & $1.11-1.68$ & \\
\hline & & A & $137(35.5 \%)$ & $316(41.76 \%)$ & & 0.77 & $0.60-0.90$ & \\
\hline & \multirow[t]{3}{*}{ Genotype } & G G & $81(41.7 \%)$ & $128(34.2 \%)$ & reference & & & \\
\hline & & G A & $88(45.8 \%)$ & $180(48.1 \%)$ & 0.18 & 0.93 & $0.64-1.28$ & 0.14 \\
\hline & & A A & $24(12.5 \%)$ & $66(17.6 \%)$ & 0.04 & 0.57 & $0.33-99$ & \\
\hline & \multirow[t]{2}{*}{ Carriers of } & $\mathrm{A}+$ & $112(58.3 \%)$ & $246(65.8 \%)$ & 0.07 & 0.71 & $0.50-1.03$ & \\
\hline & & A- & $81(41.7 \%)$ & $128(34.2 \%)$ & & 1.40 & $0.97-1.99$ & \\
\hline \multirow[t]{7}{*}{$J o 31 G>T$} & \multirow[t]{2}{*}{ Allele } & G & $253(63.2 \%)$ & $425(56.5 \%)$ & 0.03 & 1.32 & $1.03-1.69$ & \\
\hline & & $\mathrm{T}$ & $147(36.8 \%)$ & $327(43.5 \%)$ & & 0.76 & $0.59-0.97$ & \\
\hline & \multirow[t]{3}{*}{ Genotype } & G G & $80(40.0 \%)$ & $118(31.4 \%)$ & reference & & & \\
\hline & & G T & $93(46.5 \%)$ & $189(50.3 \%)$ & 0.39 & 0.86 & $0.61-1.21$ & 0.08 \\
\hline & & $\mathrm{T} \mathrm{T}$ & $27(13.5 \%)$ & $69(18.4 \%)$ & 0.14 & 0.69 & $0.43-1.23$ & \\
\hline & \multirow[t]{2}{*}{ Carriers of } & $\mathrm{A}+$ & $120(60.0 \%)$ & $258(68.6 \%)$ & 0.04 & 0.68 & $0.48-0.98$ & \\
\hline & & A- & $80(40.0 \%)$ & 118 (31.4\%) & & 1.46 & $1.02-2.08$ & \\
\hline
\end{tabular}

We found that of the five polymorphisms studied in the CTLA-4 gene, three of them (CTLA-4c.49A $>\mathrm{G}, \mathrm{CT} 60$, and Jo31) were significantly associated with MM. We observed that CTLA-4c.49A $>\mathrm{G}[\mathrm{G}]$ allele, the Jo31[G] allele and [GG] genotype and the CT60[G] allele increased the risk of developing MM.

It is of great interest that genetic variants of the studied polymorphisms have been previously reported to contribute to a lower expression level of mRNA and/or CTLA-4 molecule expression on T-cells $[16,21,23,39]$. CTLA$4 \mathrm{c} .49 \mathrm{~A}>\mathrm{G}$ transition is a functional polymorphism which influences T-cell activation and therefore might play a role in altered T-cell regulation. Presence of [GG] genotype was shown to be associated with significantly higher activation of $\mathrm{T}$ lymphocytes and higher proliferation than [AA] genotype. The protein product coded by $C T L A-4 \mathrm{c} .49 \mathrm{~A}>\mathrm{G}$ [GG] genotype CTLA $-4{ }^{17}$ Ala had lower capacity to bind B7.1 and a weaker inhibitory effect on T-cell activation compared with CTLA- $4{ }^{17} \mathrm{Thr}$ [40]. It has also been postulated that the CTLA-4c.49A $>\mathrm{G}$ polymorphism in the leader sequence may influence rates of endocytosis or surface trafficking [21], the glycosylation of CTLA-4, and 
Table 5 Haplotype estimation analysis of investigated polymorphisms within CTLA-4 gene

\begin{tabular}{|c|c|c|c|c|c|c|}
\hline $\begin{array}{l}C T L A-4 \mathrm{c} .49 \mathrm{~A}>\mathrm{G} / \\
C T L A-4 \mathrm{~g} .319 \mathrm{C}>\mathrm{T} / \\
C T L A-4 \mathrm{~g} . * 642 \mathrm{AT}(8-32) / \\
\text { CT60 G }>\mathrm{A} / \\
\text { Jo31 G }>\mathrm{T}\end{array}$ & $\begin{array}{l}\text { Multiple myeloma } \\
n=200\end{array}$ & $\begin{array}{l}\text { Controls group } \\
n=380\end{array}$ & OR & $95 \% \mathrm{CI}$ & $\mathrm{p}$ & $\mathrm{p}_{\text {after Bonferroni correction }}$ \\
\hline A C 8 AT & $97.72(0.28)$ & $256.28(0.36)$ & 0.70 & {$[0.53 \sim 0.94]$} & 0.02 & 0.1 \\
\hline $\mathrm{A} \mathrm{C}>8 \mathrm{G} \mathrm{G}$ & $22.61(0.07)$ & $36.35(0.05)$ & 1.33 & {$[0.78 \sim 2.29]$} & 0.30 & \\
\hline $\mathrm{AT}>8 \mathrm{G} \mathrm{G}$ & $24.02(0.07)$ & $50.04(0.07)$ & 1.01 & {$[0.61 \sim 1.68]$} & 0.97 & \\
\hline G C 8 AT & $16.54(0.05)$ & $17.21(0.03)$ & 2.08 & {$[1.04 \sim 4.14]$} & 0.03 & 0.15 \\
\hline G C $8 \mathrm{G} \mathrm{G}$ & $30.33(0.09)$ & $18.17(0.03)$ & 3.79 & {$[2.08 \sim 6.89]$} & $3.67 \mathrm{e}-006$ & $1.0 \mathrm{e}-005$ \\
\hline $\mathrm{G} \mathrm{C}>8 \mathrm{G} \mathrm{G}$ & $111.33(0.32)$ & $257.64(0.37)$ & 0.854 & {$[0.64 \sim 1.13]$} & 0.27 & \\
\hline
\end{tabular}

Global result:

Total control $=700.0$, total case $=346.0$, Global chi2 is 29.923019 while $\mathrm{df}=5$, Fisher's $\mathrm{p}$ value is $1.58 \mathrm{e}-005$, $\mathrm{p}_{\text {after Bonferroni correction }}=7.5 \mathrm{e}-005$

intracellular/surface partitioning, and in that way alter inhibitory function of that molecule [16]. Our previous results indicated that presence of $\mathrm{G}$ alleles in polymorphic sites CT60 and Jo31 was associated with the lower levels of membrane and cytoplasmic CTLA-4 in CD4+ T lymphocytes from multiple sclerosis patients [23] and with the variation of the serum soluble CTLA-4 level in GravesGraves' disease patients [24].

In fact a marked reduction, particular in advanced stage of MM, in the proportion of CD4 and CD8 cells expressing CTLA-4, CD28, CD3zeta, p561ck, ZAP-70 and PI3-k, what indicate that profound and multiple T-cell signalling defects, from the surface and down-stream, consistent with involvement of a master T-cell function, especially in advanced stage MM [1].

In the only report about an association of CTLA-4 gene polymorphism and MM published previously by Zheng et al. [15], the prevalence of longer CTLA-4g.*642AT(8_33) alleles, which are associated with lower stability of mRNA for CTLA-4 was described. In our study we also observed nonsignificantly increased frequency of longer alleles.

Our findings regarding CTLA-4 gene polymorphisms and susceptibility to $\mathrm{MM}$ are different from those we obtained for B-cell chronic lymphocytic leukaemia (B-
CLL) [9], in which the CTLA-4g.319C $>\mathrm{T}[\mathrm{T}]$ allele was significantly associated with disease. Although it seems surprising, population studies based on a positive family history of lymphoproliferative neoplasms indicated that the genetic pathway involved in the etiology of chronic lymphocytic leukemia (CLL), non-Hodgkin's lymphoma (NHL), and Hodgkin's lymphoma (HL) is different from that of MM. It was shown that first-degree relatives of chronic CLL patients are at higher risk of developing CLL, NHL, and HL, but not at increased risk of developing MM [41, 42]. In contrast, first-degree relatives of MM patients are not at risk of developing B-CLL, CLL, NHL, or HL [17].

A limitation of this study is the relatively small group of patients, but it should be mentioned that the population risk of $\mathrm{MM}$ is approximately 0.00003 and it is difficult to collect a bigger homogeneous ethnically matched cohort. Therefore our findings should be confirmed by an independent study on a larger cohort.

Our original findings of the prevalence of the CTLA4c.49A $>\mathrm{G}[\mathrm{G}]$, Jo31[G], and CT60[G] alleles suggested that genetic variations in the CTLA-4 gene play a role in multiple myeloma and warrant further investigation through replication studies.

Table 6 Linkage disequilibrium analysis in CTLA-4 gene

\begin{tabular}{|c|c|c|c|c|c|c|c|c|}
\hline & \multicolumn{2}{|c|}{$C T L A-4 \mathrm{c} .49 \mathrm{~A}>\mathrm{G}$} & \multicolumn{2}{|c|}{ CTLA-4g.*642AT(8_33) } & \multicolumn{2}{|l|}{ CT60 } & \multicolumn{2}{|l|}{ Jo31 } \\
\hline & $\mathrm{D}^{\prime}$ & $r^{2}$ & $\mathrm{D}^{\prime}$ & $r^{2}$ & $\mathrm{D}^{\prime}$ & $r^{2}$ & $\mathrm{D}^{\prime}$ & $r^{2}$ \\
\hline$C T L A-4 \mathrm{~g} .319 \mathrm{C}>\mathrm{T}$ & 0.883 & 0.074 & 0.546 & 0.028 & 0.906 & 0.060 & 0.805 & 0.050 \\
\hline$C T L A-4 \mathrm{c} .49 \mathrm{~A}>\mathrm{G}$ & & & 0.567 & 0.237 & 0.769 & 0.320 & 0.770 & 0.353 \\
\hline CTLA-4g.*642AT(8_33) & & & & & 0.924 & 0.651 & 0.818 & 0.537 \\
\hline СТ60 & & & & & & & 0.901 & 0.752 \\
\hline
\end{tabular}


Acknowledgement This study was supported by a grant from the Polish State Committee for Scientific Research (KBN, No. 2PO5B 047 28).

Conflict of interests The authors declare that they have no competing interests.

Contributions to the study LK designed of the study, genotyped and drafted the manuscript (MS); EP, AJ, AT, AJ analyses and interpretation; MK, SP, DW clinical survey, KK revised the MS, IF was the guarantor. All authors approved the manuscript

Open Access This article is distributed under the terms of the Creative Commons Attribution Noncommercial License which permits any noncommercial use, distribution, and reproduction in any medium, provided the original author(s) and source are credited.

\section{References}

1. Mozaffari F, Hansson L, Kiaii S, Ju X, Rossmann ED, Rabbani H, Mellstedt H, Osterborg A (2004) Signalling molecules and cytokine production in $\mathrm{T}$ cells of multiple myeloma-increased abnormalities with advancing stage. Br J Haematol 124:315-324

2. Bianchi A, Mariani S, Beggiato E, Borrione P, Peola S, Boccadoro M, Pileri A, Massaia M (1997) Distribution of Tcell signalling molecules in human myeloma. $\mathrm{Br} \mathrm{J}$ Haematol 97:815-820

3. Brown RD, Pope B, Yuen E, Gibson J, Joshua DE (1998) The expression of T cell related costimulatory molecules in multiple myeloma. Leuk Lymphoma 31:379-384

4. Frassanito MA, Cusmai A, Dammacco F (2001) Deregulated cytokine network and defective Th1 immune response in multiple myeloma. Clin Exp Immunol 125:190-197

5. Murakami H, Ogawara H, Hiroshi H (2004) Th1/Th2 cells in patients with multiple myeloma. Hematology 9:41-45

6. Hilbert DM, Shen MY, Rapp UR, Rudikoff S (1995) T cells induce terminal differentiation of transformed B cells to mature plasma cell tumors. Proc Natl Acad Sci USA 92:649-653

7. Walunas TL, Lenschow DJ, Bakker CY, Linsley PS, Freeman GJ, Green JM, Thompson CB, Bluestone JA (1994) CTLA-4 can function as a negative regulator of $\mathrm{T}$ cell activation. Immunity $1: 405-413$

8. Valk E, Rudd CE, Schneider H (2008) CTLA-4 trafficking and surface expression. Trends Immunol 29:272-279

9. Suwalska K, Pawlak E, Karabon L, Tomkiewicz A, Dobosz T, Urbaniak-Kujda D, Kuliczkowski K, Wolowiec D, Jedynak A, Frydecka I (2008) Association studies of CTLA-4, CD28, and ICOS gene polymorphisms with B-cell chronic lymphocytic leukemia in the Polish population. Hum Immunol 69:193-201

10. Erfani N, Razmkhah M, Talei AR, Pezeshki AM, Doroudchi M, Monabati A, Ghaderi A (2006) Cytotoxic T lymphocyte antigen-4 promoter variants in breast cancer. Cancer Genet Cytogenet 165:114-120

11. Ghaderi A, Yeganeh F, Kalantari T, Talei AR, Pezeshki AM, Doroudchi M, Dehaghani AS (2004) Cytotoxic T lymphocyte antigen-4 gene in breast cancer. Breast Cancer Res Treat 86:1-7

12. Piras G, Monne M, Uras A, Palmas A, Murineddu M, Arru L, Bianchi A, Calvisi A, Curreli L, Gaviano E, Lai P, Murgia A, Latte GC, Noli A, Gabbas A (2005) Genetic analysis of the 2q33 region containing CD28-CTLA4-ICOS genes: association with nonHodgkin's lymphoma. Br J Haematol 129:784-790
13. Su TH, Chang TY, Lee YJ, Chen CK, Liu HF, Chu CC, Lin M, Wang PT, Huang WC, Chen TC, Yang YC (2007) CTLA-4 gene and susceptibility to human papillomavirus-16-associated cervical squamous cell carcinoma in Taiwanese women. Carcinogenesis 28:1237-1240

14. Wong YK, Chang KW, Cheng CY, Liu CJ (2006) Association of CTLA-4 gene polymorphism with oral squamous cell carcinoma. J Oral Pathol Med 35:51-54

15. Zheng C, Huang D, Liu L, Bjorkholm M, Holm G, Yi Q, Sundblad A (2001) Cytotoxic T-lymphocyte antigen-4 microsatellite polymorphism is associated with multiple myeloma. $\mathrm{Br} \mathrm{J}$ Haematol 112:216-218

16. Anjos S, Nguyen A, Ounissi-Benkalha H, Tessier MC, Polychronakos C (2002) A common autoimmunity predisposing signal peptide variant of the cytotoxic T-lymphocyte antigen 4 results in inefficient glycosylation of the susceptibility allele. J Biol Chem 277:46478-46486

17. Wang XB, Zhao X, Giscombe R, Lefvert AK (2002) A CTLA-4 gene polymorphism at position -318 in the promoter region affects the expression of protein. Genes Immun 3:233-234

18. Chistiakov DA, Savost'anov KV, Turakulov RI, Efremov IA, Demurov LM (2006) Genetic analysis and functional evaluation of the $\mathrm{C} / \mathrm{T}(-318)$ and $\mathrm{A} / \mathrm{G}(-1661)$ polymorphisms of the CTLA-4 gene in patients affected with Graves' disease. Clin Immunol 118:233-242

19. Ligers A, Teleshova N, Masterman T, Huang WX, Hillert J (2001) CTLA-4 gene expression is influenced by promoter and exon 1 polymorphisms. Genes Immun 2:145-152

20. Donner H, Braun J, Seidl C, Rau H, Finke R, Ventz M, Walfish PG, Usadel KH, Badenhoop K (1997) Codon 17 polymorphism of the cytotoxic T lymphocyte antigen 4 gene in Hashimoto's thyroiditis and Addison's disease. J Clin Endocrinol Metab 82:4130-4132

21. Kouki T, Sawai Y, Gardine CA, Fisfalen ME, Alegre ML, DeGroot LJ (2000) CTLA-4 gene polymorphism at position 49 in exon 1 reduces the inhibitory function of CTLA- 4 and contributes to the pathogenesis of Graves' disease. J Immunol 165:6606-6611

22. Wang XB, Kakoulidou M, Giscombe R, Qiu Q, Huang D, Pirskanen R, Lefvert AK (2002) Abnormal expression of CTLA4 by $\mathrm{T}$ cells from patients with myasthenia gravis: effect of an ATrich gene sequence. J Neuroimmunol 130:224-232

23. Karabon L, Kosmaczewska A, Bilinska M, Pawlak E, Ciszak L, Jedynak A, Jonkisz A, Noga L, Pokryszko-Dragan A, Koszewicz M, Frydecka I (2009) The CTLA-4 gene polymorphisms are associated with CTLA-4 protein expression levels in multiple sclerosis patients and with susceptibility to disease. Immunology 128:e787-e796

24. Daroszewski J, Pawlak E, Karabon L, Frydecka I, Jonkisz A, Slowik M, Bolanowski M (2009) Soluble CTLA-4 receptor an immunological marker of Graves' disease and severity of ophthalmopathy is associated with CTLA-4 Jo31 and CT60 gene polymorphisms. Eur J Endocrinol 161:787-793

25. Criteria for the classification of monoclonal gammopathies, multiple myeloma and related disorders: a report of the International Myeloma Working Group. Br J Haematol 121:749-757, 2003

26. Greipp PR, San MJ, Durie BG, Crowley JJ, Barlogie B, Blade J, Boccadoro M, Child JA, vet-Loiseau H, Kyle RA, Lahuerta JJ, Ludwig H, Morgan G, Powles R, Shimizu K, Shustik C, Sonneveld P, Tosi P, Turesson I, Westin J (2005) International staging system for multiple myeloma. J Clin Oncol 23:3412-3420

27. Ploski R, Wozniak M, Pawlowski R, Monies DM, Branicki W, Kupiec T, Kloosterman A, Dobosz T, Bosch E, Nowak M, Lessig R, Jobling MA, Roewer L, Kayser M (2002) Homogeneity and distinctiveness of Polish paternal lineages revealed by Y chromosome microsatellite haplotype analysis. Hum Genet 110:592-600 
28. Shi YY, He L (2005) SHEsis, a powerful software platform for analyses of linkage disequilibrium, haplotype construction, and genetic association at polymorphism loci. Cell Res 15:97-98

29. Landgren O, Linet MS, McMaster ML, Gridley G, Hemminki K, Goldin LR (2006) Familial characteristics of autoimmune and hematologic disorders in 8,406 multiple myeloma patients: a population-based case-control study. Int J Cancer 118:3095-3098

30. Zheng C, Huang D, Liu L, Wu R, Bergenbrant GS, Osterborg A, Bjorkholm M, Holm G, Yi Q, Sundblad A (2001) Interleukin-10 gene promoter polymorphisms in multiple myeloma. Int $\mathrm{J}$ Cancer 95:184-188

31. Mazur G, Bogunia-Kubik K, Wrobel T, Karabon L, Polak M, Kuliczkowski K, Lange A (2005) IL-6 and IL-10 promoter gene polymorphisms do not associate with the susceptibility for multiple myeloma. Immunol Lett 96:241-246

32. Brown EE, Lan Q, Zheng T, Zhang Y, Wang SS, Hoar-Zahm S, Chanock SJ, Rothman N, Baris D (2007) Common variants in genes that mediate immunity and risk of multiple myeloma. Int $\mathrm{J}$ Cancer 120:2715-2722

33. Lincz LF, Kerridge I, Scorgie FE, Bailey M, Enno A, Spencer A (2004) Xenobiotic gene polymorphisms and susceptibility to multiple myeloma. Haematologica 89:628-629

34. Hayden PJ, Tewari P, Morris DW, Staines A, Crowley D, Nieters A, Becker N, de SS, Foretova L, Maynadie M, Cocco PL, Boffetta P, Brennan P, Chanock SJ, Browne PV, Lawler M (2007) Variation in DNA repair genes XRCC3, XRCC4, XRCC5 and susceptibility to myeloma. Hum Mol Genet 16:3117-3127

35. Hosgood HD III, Baris D, Zhang Y, Berndt SI, Menashe I, Morton LM, Lee KM, Yeager M, Zahm SH, Chanock S, Zheng T, Lan Q (2009) Genetic variation in cell cycle and apoptosis related genes and multiple myeloma risk. Leuk Res 33:1609-1614

36. Mayans S, Lackovic K, Nyholm C, Lindgren P, Ruikka K, Eliasson M, Cilio CM, Holmberg D (2007) CT60 genotype does not affect CTLA-4 isoform expression despite association to T1D and AITD in northern Sweden. BMC Med Genet 8:3

37. Gough SC, Walker LS, Sansom DM (2005) CTLA4 gene polymorphism and autoimmunity. Immunol Rev 204:102-115

38. Ihara K, Ahmed S, Nakao F, Kinukawa N, Kuromaru R, Matsuura N, Iwata I, Nagafuchi S, Kohno H, Miyako K, Hara T (2001) Association studies of CTLA-4, CD28, and ICOS gene polymorphisms with type 1 diabetes in the Japanese population. Immunogenetics 53:447-454

39. Ueda H, Howson JM, Esposito L, Heward J, Snook H, Chamberlain G, Rainbow DB, Hunter KM, Smith AN, Di GG, Herr MH, Dahlman I, Payne F, Smyth D, Lowe C, Twells RC, Howlett S, Healy B, Nutland S, Rance HE, Everett V, Smink LJ, Lam AC, Cordell HJ, Walker NM, Bordin C, Hulme J, Motzo C, Cucca F, Hess JF, Metzker ML, Rogers J, Gregory S, Allahabadia A, Nithiyananthan R, Tuomilehto-Wolf E, Tuomilehto J, Bingley P, Gillespie KM, Undlien DE, Ronningen KS, Guja C, IonescuTirgoviste C, Savage DA, Maxwell AP, Carson DJ, Patterson CC, Franklyn JA, Clayton DG, Peterson LB, Wicker LS, Todd JA, Gough SC (2003) Association of the T-cell regulatory gene CTLA4 with susceptibility to autoimmune disease. Nature 423:506-511

40. Sun T, Zhou Y, Yang M, Hu Z, Tan W, Han X, Shi Y, Yao J, Guo Y, Yu D, Tian T, Zhou X, Shen H, Lin D (2008) Functional genetic variations in cytotoxic T-lymphocyte antigen 4 and susceptibility to multiple types of cancer. Cancer Res 68:7025-7034

41. Goldin LR, Pfeiffer RM, Gridley G, Gail MH, Li X, Mellemkjaer L, Olsen JH, Hemminki K, Linet MS (2004) Familial aggregation of Hodgkin lymphoma and related tumors. Cancer 100:1902-1908

42. Goldin LR, Pfeiffer RM, Li X, Hemminki K (2004) Familial risk of lymphoproliferative tumors in families of patients with chronic lymphocytic leukemia: results from the Swedish Family-Cancer Database. Blood 104:1850-1854 